\title{
WOMEN AND SAMBEN SPACE: TOURISM GLOBALIZATION AND TRADITION IN KASONGAN
}

\author{
KARMILAH, Mila ${ }^{1 *}$; NURYANTI, Wiendu ${ }^{2}$; SUWARNO, Nindyo ${ }^{3}$; SETIAWAN, Bakti ${ }^{4}$ \\ ${ }^{1}$ Faculty member Department of Urban and Regional Planning Unissula Semarang, Indonesia \\ Ph.D candidate Department of Architecture and Planning UGM Yogyakarta, Indonesia \\ ${ }^{2,3,4}$ Professor, Department of Architecture and Planning GMU Yogyakarta, Indonesia \\ Emails: wiendu@gmail.com,nindyosuwarno@yahoo.com \\ *Corresponding Author: karmilahmila@gmail.com
}

\begin{abstract}
The involvement of women in economic activities is a phenomenon that has lasted a long time. An overview of the extensive-role of women confirms that women's involvement context becomes very important to note. One of phenomenon is the "samben" space. The emergence of samben space is a form of adaptation of Kasongan women addressing the growing tourism globalization. In Javanese tradition, women are always become a wife and mother to guard their house. On the other hand, they are also willing to help the family economy by working at home. For this situation they call samben. So the phenomenon of women working from home with an exploration of the whole part of the house is a way for women to adapt to the present but at the same time maintaining cultural traditions to remain a mother and wife.
\end{abstract}

Keywords: Women and Samben; tourism globalization; Kasongan.

\section{INTRODUCTION}

The involvement of women in economic activities in the countryside is a phenomenon that has lasted a long time. An overview of the extensive role of women confirms that women's involvement context becomes very important to note. Craft activity is a form of domestic activities, and has a fairly long history (Soeroto and Hatmosuprobo, 1979). The emergence of these activities certainly can not be attributed directly to the agricultural sector to absorb setbacks labor (Abdullah, 1995), but also a function of the differentiation of economic activities in the economic structure of the region.

Establishment of a housing area basically is determined by various factors, including the local culture. How individuals relate to the family and the surrounding environment is certainly different from one culture to another culture, then how the space was laid out and designed it is dependent on each worldview (culture, religion and etc) (Dansby, 1993: 137)

\section{LITERATURE REVIEW}

\section{Gender and Space}

According to Harvey (1990) and Soja (1989) in (Rendell, 2007: 101-102) that space is of socially produced, but that space is also a result of social production. They also stated that space is the mate- rially and culturally produced and the architecture is the one of form of culturally produced artefact. As material culture, space are becoming an integral part of everyday life, socially bound, in private life and activity.

Anthropology was one of the first disciplines to suggest that there was a relation between gender and space, and thas it was defined through power relations. According to anthropology and geography that is a spatial perspective of social and cultural production, while gender relations are constructed by social, cultural and spatial.

\section{Public Space and Private Space}

Lefebvre (1991) stated that the social production of space to work through three (3) different ways, namely spatial practice (material or function space), representations of space (space as sign language) and representational space (space as a means of selfactualization day-to-day). Public space and private space in segrasi have shown the position of women, men would be identical to that public space is identified with the production function (work, earn a living), while women who identified with reproductive function (childbirth, cooking, etc.) are identical to the private sphere. This is caused by the patriarchal culture and capitalist culture.

The problem of sex, space and gender ideology not only problems in the division of space, but also deconstructed by viewpoint binary hierarchical. 


\section{Reproductive Role and Productive Role}

The background of the rise of the domestic sphere and the public is considered derived from the division of labor based on gender is popularly known as gender. Traditional gender division of labor (gender base division of labour) puts the division of labor, women in the home (domestic sector) and men work outside the home (the public sector). Such a division of labor is considered standart by most of society and reinforced by the Marriage Act.

This division of labor as feminists often referred to as the sexual division of labor, which is a regulated process of hierarchical work, which creates a subordinate job categories are grouped by gender and gender specific stereotypes. This sexual division of labor has given birth to a typical work of women who occupy subordinate hierarchical, so therefore he valued lower. Typical work for each sex is generally associated with sexual roles, so the technical term productive work for men and for women's reproducetive work.

Productive work is a work process that produces something (a product). In a capitalist society it is usually something that is generated is defined by the exchange rate. In the discussion of gender, the concept of productive work is often associated as public works (public sector). Therefore, the domestic work done by women, such as cooking which also produces something for family consumption is often regarded not as the work of production (reproductive work) (Rustiani, 1996).

\section{Globalization and Industrialization}

Fakih (2004) states that globalization is in fact a process of integration of national economics of the nations into a global economic system. Also globalization is one phase of a long journey liberal capitalist development, which theoretically has been developed by Adam Smith. In other words, globalization is a phase of colonialism rich countries to poor countries or developing countries. Hence, the beginning of globalization is a term of a country's economy.

The growing interconnection of world activities is undoubtedly one of the most significant developments of the recent years. Globalization has brought with it such an internationalization of economic transactions that activities that were essentially explained in terms of national economy in the past have sought other financing channels such as the Maquila (Dicken, 1992; Perraton, Goldblatt, Held, and McGrew, 1997) in Berruecos, 2008.
Globalization has also affected the cultural sphere. Economic globalization implies alliances, which force societies to reorganize the political sphere, and in turn serve to favor and strengthen the economic position of transnational enterprises that have established an internationally commercial regime (Harvey, 1990; Ohae, 1995). Some authors agree that the economy is not changing but rather transforming itself in its structural basis. This process, they assert, is irreversible, and global markets have placed national states in an irrelevant (and/or perhaps unrecognized) position. Consequently, the debate revolves around the emphasis that scholars give to one or many of the elements that form part of the core of globalization (Cohen, 1988; Giddens, 2000) in Berruecos, 2008.

Thee, 1993 suggests that the development of small industry is the way it assessed a large role in the development of industry. small scale industries development will help address the unemployment problem of the technologies used are labor intensive technologies, thereby expanding employment, business opportunities, which in turn encourages the development of local or regional globalization is one phase of a long journey liberal capitalist development, which theoretically has been developed by Adam Smith.

\section{RESEARCH METHOD}

This type of research is very important. In the context of this study, consideration is to be able to capture the pattern of kinship that supported the production chain in pottery to be a major aspect in this study. Therefore the aspect of "depth" is an important consideration in selecting and implementing research strategies. This question refers to the right kind of research is qualitative research from a gender perspective.

Moleong (2001) cites the opinion of some authors (Willens and Rausch, 1969; Bogdan and Taylor, 1975; Denzin and Lincoln, 1994). Natsir (1988) and Yin (2005) stated that qualitative research is a research that aims to understand the phenomenon of what is experienced by the subject (behavior, perception, motivation, action, etc.) in a holistic manner, and by way of description in the form of words and language, in a specific context natural and by using various natural methods. This kind of coluoring all stages of research studies conducted, including the selection of strategies or methods of research and analysis. In this context, the method or strategy is suitable qualitative research. 
Phenomenology is designed to considering the perception of the participants. This is a major focus of research. Through exploration of everyday experience and discover the meaning behind the empirical phenomena (Casmir, 1983; Mac Dermott, 2002), while according to Marleau Ponty, 1962, the psychological condition participants also become the key to success in revealing phenomena. Thus the phenomenological approach can be used by various disciplines such as tourism research that focuses on understanding of people's experience (Casmir, 1983).

To get proper knowledge about space in the village samben Kasongan, then used a particular research method (phenomenology) so as to express uniqueness, and understand the meanings behind the reality. The main character of this approach is to promote the meaning, context and emic perspective, concerned with the depth of information than the scope of the study. Qualitative research in trying to understand the phenomenology paradigm (for meaning) of the event and its linkages with the ordinary people in particular situations (Moleong, 2001).

\section{DISCUSSION}

Indonesian dictionary word of "samben" means work performed after the main work has been completed. The word is usually identic with women, because women in Javanese culture, largely remains as a housewife. Even if they have no work then it happens urban. Kasongan as pottery village, has long been known. The work of making pottery since time immemorial has become dominated by women's work, not only in Kasongan but almost pottery village in Indonesia such as the village of Bayat, Banyu muelek village and other pottery villages. This can be seen in the following picture of how women become pottery maker.

In the beginning only because of its function as a household appliance that this work acted by women. At this time the influx of modernization and globalization of pottery that used only as a household appliance has now transformed into a tool to decorate the room (the interior of the house). This change also occurred resulting in an employment structure changes in pottery maker particularly women. Currently potters work by women was considered as a "samben", meaning that only worked if the housework

Completed work such as cooking, washing or raise their children. As stated by some authorities following.

.........ki disambi kalean masak mbak, mangke ndamel guci maleh nek sampun rampung gawe anteng omah, .....
.........I do this side job to make a vases and many kind of pottery, after doing my main job as a wife like cooking and other job at home as my duty.........

To make pottery the women using terrace of th house or any other location in the house as long as they can work at house.So that requires women to be good in allocating the time. One of the women pottery said that, she is willing to make an extra time that is bound to be late into the night to complete the task of making pottery, even they do a lot of work and spending extra time until late, women pottery always said that what they have done it is a "samben" or side job. As presented by the following speakers;

.................kalo gak kerja ngapain mbak...yaa momong, (sambil tertawa) jadi kerjanya jam berapa sampe jam berapa, kalo pagis aya nyambi, malam baru kerja, ooh malam baru kerja, maksudnya sedapetnya lhaa itu ada anak kecil umur berapa mbk, 1,5 tahun, kalo malem pas banyak pesenanya sampe pagi, jadi kalo pagi kerjanya apa mbak, cuci baju, kalo gak liburanyaa nyiapin anak sekolah, Cuma ngurusin anak itu, kalo pas anak tidur bisa kerja, kalo masak sama ibu,

.................if $i$ didn't made a pottery so I was take care my children, so what time your made a pottery, in the morning I just doing a pottery only if I don't have work (as side job only), after my children was going to bed and my job already finish so I can focus to make a pottery, and if I have a lot of order I have to spend more time until lateeven till morning, ............................

In order for the main job do not interrupted (such as cooking and raise their children) make the women always made their activities as a wife and a mother near by they make a pottery. The Location as seen in some of the following visualization. This is done solely for their main job as a mother can still be done while still doing the job of making pottery which they are odd jobs (samben).

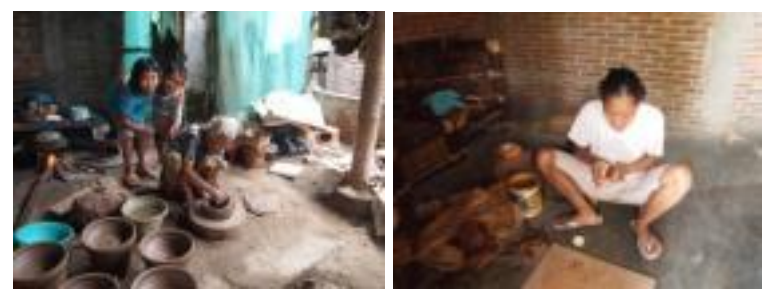

Figure 1. A vary spaces that women uses to make a pottery 


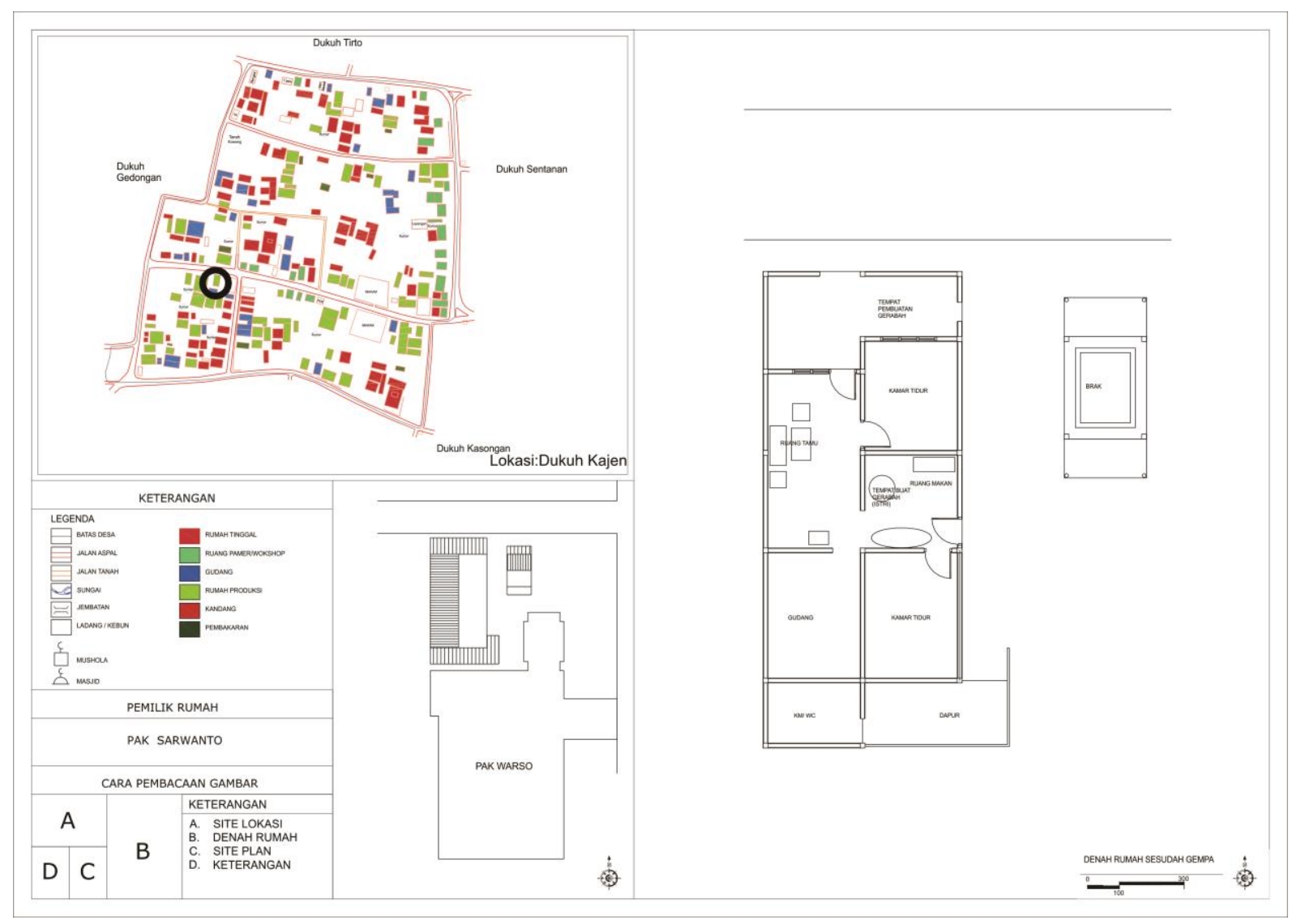

Figure 2. A location that women make pottery near their kitchen

Due to the desire of women to participate (exist) not only in the reproductive roles (cooking, childbirth, raise the children) that is often attached to the female gender but also in productive roles. On the other hand they are also willing to participate in a productive space in this case as a pottery craftsman that requires women to overcome the limitations of space or motion (working from home). To overcome these obstacles women typically will use always bring jobs (making pottery) they move (sometimes carried out on the porch, in the kitchen or in the living room) so depending on where women perform their main activity. Work to make pottery by women only odd jobs, so they assume that the odd jobs will follow the main job (as a mother and wife).

\section{CONCLUSION}

Globalization and modernization that occurred in the formal industrial sector also occur in the home industry with different shapes. Form of work done by women in Kasongan is work to be done at home or they take jobs at larger employers, then worked at home, they even call it a sidejob (samben). In fact, as mentioned in the previous section that the work is acted by women are low-paying jobs (usually with a contract system) without any limitation of time, such as that delivered some of the informants, they can work on multiple orders at once (two or more), but it worked at night time (after doing activities related to their function as a housewife) found production organization has successfully confirmed and maintain what is referred to as a domestic ideology, the ideology of women who stay at home.

Spaces are formed with an understanding of women that their primary duty is as a housewife bringing consequences to the existence of the spaces they use. All of women stated that to still be able to do the job once prolific reproductive work is made in part or the whole house as a work location (braK). Physical boundaries of the house become unclear/ blurred between production and reproduction spaces. In fact there is a tendency to be unbeaten reproduction space with space in the name of industrial production of small pottery.

\section{REFERENCES}

Abdullah, I. (1995). Seks, Gender \& Reproduksi Kekuasaan, Yogjakarta: Tarawang Press.

Berruecos (2008). The Quality of Social Existence in an Indian Community in Mexico due to Globali- 
zation, in American Behavioral Scientist Sage Publication, 1-19.

Bogdan and Taylor (1975). Introduction to Qualitative Research Methods: A Phenomenological Approaches to Social Science. New York: John Wiley \& Sons.

Casmir, F.I. (1983). Phenomenology and Hermeneutics: Evolving Approaches to the Study of Intercultural and International Communication. International Journal of Intercultural Relation, 7, 309-324.

Cohen, B. (1988). Global perspectives: The total culture system in the Modern World, Codek, London.

Dansby, M.R. (1993). Cultural Diversity and Gender Issues, in C. Cronin (ed) Military Psychology, New York: Simon and Schuster.

Denzin, N.K. and Lincoln, Y.S. (Eds) (1994). Handbook of Qualitative Research, Thousand Oaks, CA: Sage

Dicken, P. (1992). Global shift, (2 ${ }^{\text {nd }}$ ed.). London: Paul Chapman.

Fakih, M. (2004). Runtuhnya Teori Pembangunan dan Globalisasi, Yogjakarta: Pustaka Pelajar.

Giddens, A. (2000). The Third Way and its critics, UK: Polity Cambridge.

Harvey, D. (1990). The Condition of Postmodernity, Oxford, Blackwell Massachusetts.

Levebref, H. (1991). The Production of Space, Oxford, UK: Blackwell Publisher Ltd.
Mac Dermot (2002). Introduction to Phenomenology, London and New York: Routledge Taylor and Francis Group.

Moleong, L. (2001). Metodologi Penelitian Kualitatif, PT. Remaja Rosdakarya Bandung

Natsir (1988). Metode Penelitian, Ghalia Indonesia Jakarta.

Ohae, K. (1995). The End of the Nation State, London: Harper Collins.

Perraton, J., Goldblatt, D., Held, D. and McGrew, A. (1997). The globalization of economic activity, New Political Economy, 2(2), 257-278.

Rendell, J. (2007). "Gender Space and Arhitecture: An interdisciplinary introduction", London and New York: Routledge Taylor \& Francis Group.

Rustiani, F. (1996). Istilah-istilah Umum dalam Wacana Gender, dalam Jurnal Analisis Sosial: Analisis Gender dalam Memahami Persoalan Perempuan, Edisi 4 November 1996 Yayasan AKATIGA Bandung, 57-60

Soja, E. (1989). Postmodern Geographies: The Reassertion of Space in Social Theory, London: Verso.

Soeroto, S. and Hatmosuprobo, S. (1979). Laporan Penelitian tentang Industri Rakyat Klaten (Suatu Tinjauan Historis Antropologis), LP3ES Jakarta

Willens, E. and Rausch, H. (1969). Naturalistic Viewpoints in Psychological Research, Holt, New York: Rinehart and Winston.

Yin (2005). Penelitian Studi Kasus: Desain dan Metode, Sage, Thousand Oaks CA. 